Basil Lourié

Saint Petersburg State University of Aerospace Instrumentation

Saint Petersbourg, Russia

hieromonk@gmail.com

\title{
NOTES ON MAR PINḦAS:
}

\section{A "Nestorian" Foundation Legend; the Liturgy Implied; Polemics against Jewish Mysticism; an Early Christian Apology Used; Syrian Monasticism from Athens}

In his recent work Adam McCollum has reintroduced to scholarly attention a Syriac text whose first appearance in print, in the edition by Paul Bedjan in 1894, passed almost unnoticed. Now the text is republished together with an English translation and provided with commentaries and a study. ${ }^{1}$ Moreover, the editor has added a republication of an Arabic epitome of The Story of Mar Pinhas, first published by Mgr Addai Scher in 1905 in an almost inaccessible book. Both texts, Syriac and Arabic, are translated into a European language for the first time.

In light of McCollum's study this text looks even more intriguing, and I have been unable to refrain from an attempt at extending his analysis and commentary.

\section{THE PURPOSE OF THE STORY AND ITS APPROXIMATE DATING}

I will start by recapitulating McCollum's conclusions. He summarizes and enforces previous scholars' doubts or, in some cases, certitude in taking the entire fourth-century plot of the story as legendary: it is hardly probable that this text is even a remotely historical account of a martyr during the great persecution under Shapur II or ofa monk from the circle of disciples of the famous fourth-century ascetic Mar Awgen (p. xvi-xix). McCollum's most precise characterisation of the

(1) A. C. McCollum, The Story of Mar Pinhas Edited and Translated (Persian Martyr Acts in Syriac: Text and Translation, fasc. 2), Piscataway, NJ: Gorgias Press, 2013, p. xxiii, 37. 
story is placed among the commentaries: it represents "...an etiology for relics and monasticism" (p. 29).

Indeed, the story is a typical Passion épique, according to the classification of Hippolyte Delehaye. ${ }^{2}$ It is not about the fourth century, but rather reflects events contemporary to its author, particularly in the realm of Church geography and Church politics. The meaning of such stories is revealed by looking at their conclusions, that is, at the sections dealing with the destiny of the relics. This is a very important part of our story, too (§§ 11-15, p. 14/15-16/17 tr./txt). The hagiography as an etiology of relics serves to prove the "ancient rights" and the high status of the corresponding Church centre. In our case, this Church centre is an unspecified women's monastery named for Mar Pinhas in the region of the city of Cizre in modern Turkey, which is the historical Jazīrat ibn 'Umar or Gazarta/ Gzira and is known from at least the fifth century as the seat of the East Syrian bishops of Beth Zabdaï. This convent is otherwise unknown (cf. commentary on p. 29 to $\S 14$ ). Thus, with this foundation legend, the convent inscribes itself into the famous monastic tradition of Mar Awgen and the tradition of his monastery on Mt. Izla. The text itself expresses its actuality in the phrase "...and the convent was named - as it is to this day - for Mar Pinhas" (p. 16/17 tr./txt).

One can accept, to a certain extent, the historicity of the main claim of our text, that the convent belongs to the Mar Awgen and Mt. Izla tradition, despite the fact that, unlike McCollum, I am not inclined to accept any historicity of Mar Pinhas as a person. The miraculous story of the relics and the foundation of the Mar Pinhas convent involves two much more historical disciples of Mar Awgen, Mar Yabh and Mar Aha, and - what is most important - their monastery of Zarnuqa, which was a very famous historical monastery in the same Cizre region (§ 13; p. 16/17 tr./txt and commentary, p. 28).

This part of the story must be read as a mark of the patronage of the Zarnuqa monastery over the convent that produced our hagiographical legend.

The references to the epoch and the milieu of Mar Awgen and the Persian martyrs under King Shapur II serve as the substrat hagio-

(2) S. esp. H. DeleHAYE, Les passions des martyrs et les genres littéraires. Deuxième édition, revue et corrigée (Subsidia hagiographica, 13 B), Bruxelles, 1966; IDEM, Cinq leçons sur la méthode hagiographique (Subsidia hagiographica, 21), Bruxelles, 1934. 
graphique ${ }^{3}$ of our legend about Mar Pinhas: something similar to the background historical landscape for a modern historical novel. The hagiographical substrate always refers to a remote epoch of the epic past. Thus, the date of The Story of Mar Pinhas must be sufficiently late to provide enough temporal distance to consider the fourth century as the epic past. Taking into account that in this text the authority of the monastic tradition of Mt. Izla was already established, ${ }^{4}$ I think that the seventh century could be proposed as the earliest possible dating, although the Story could be even later.

\section{EAST SYRIAN ("NESTORIAN") ORIGIN}

The Church geographical setting of our story, especially because of the role of the Zarnuqa monastery, clearly belongs to the Church of the East, even though the published Syriac and Arabic manuscripts belong to the Syrian Orthodox (anti-Chalcedonian) Church. Because McCollum believes that Mar Pinhas antedated Nestorius, he was probably hesitant to acknowledge Mar Pinhas' Nestorian origins. If there is any drop of historicity in the fourth-century setting, then one cannot label the story as a whole as purely "Eastern" or "Nestorian." This is certainly the reason for the commemoration of Mar Pinhas in the Western Syrian Church as well: these Syrians believed that they were venerating an ancient martyr and not a "Nestorian" invention. However, the story has several features that prevent one from extending its historical core so far into the past.

The date of the commemoration of Mar Pinhas is 28 Nisan (April) in the Western Syrian rite and the second Friday after Easter in the Eastern Syrian rites. The Western Syrian calendars contain, in addition to this, commemorations on September 20 and October 15, but only April (Nisan) 28 is mentioned in both the Syriac and epitomised Arabic recensions as the date of his martyrdom. It is demonstrable that the date 28 Nisan is produced as a rendering of the Eastern date in the Western rite, and not vice versa.

Of course it is normal, for the Eastern Syrian rite, to commemorate martyrs on Fridays, but this specific Friday is clearly connected with

(3) For this important theoretical concept of the critical hagiography, s. M. VAN EsBROECK, "Le substrat hagiographique de la mission khazare de Constantin-Cyrille," AB, 104 (1986), pp. 338-348.

(4) Cf. the data reviewed in D. A. JoHnson, Monks of Mount Izla, [n. l.], 2004 (print on demand edition, lulu.com). 
that of the Passion: the second Friday after the Resurrection is also the second Friday after the Friday of the Passion, the first Friday after Bright Week, that is, the first Friday suitable for commemoration of a martyr. We will see, from the liturgical analysis below, that the martyrdom of Mar Pinhas as a whole is represented as a Eucharistic sacrifice. Thus, a connexion with Passion Friday is a natural part of a greater liturgical construction.

However, the Western Syrian rite normally does not allow the introduction of commemorations of the saints into the cycle of weeks related to Easter. They must be mapped onto the Julian calendar. Therefore, the date of 14 Nisan was taken as a theoretical date of Passion Friday and the Jewish Passover, and the date of the second Friday after this day became 28 Nisan/April. The fixed Julian date, by necessity, turned out to be deprived of its specific connexion to Friday.

Taking into account the following liturgical analysis, referred to above, this is compelling proof that the cult of Mar Pinhas was created within a Church worshipping according to the Eastern Syrian rite, that is, the Church of the East.

\section{THE MARTYRDOM AS THE EUCHARIST}

\subsection{A Particle of Relics as a Particle of the Eucharist}

Adam McCollum touches at one point on the liturgical presentation of the martyrdom of Mar Pinhas when he discusses why a particle of

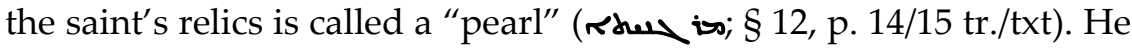
mentions that this word was used in different meanings including, among others, the Eucharistic bread, in the same manner as the Greek

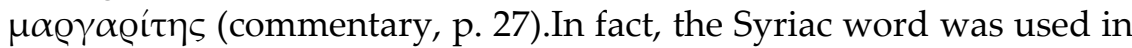
general to denote particles of saints' relics. $^{5}$ These two meanings, however, are hardly independent, the latter being obviously developed from the former. In The Story of Mar Pinhas we see a somewhat reverse process: the story explains why the "pearl" which is a particle of the relics of a martyr is, in fact, a particle of the consecrated Eucharistic body. For this purpose, the entireprocess of the martyrdom is patterned after the Eucharistic anaphora.

(5) R. PAyne SMith provides an example in his Thesaurus Syriacus, Oxford, 1868-1901, col. 2215: "sacra Apostolorum lipsana in arca reposita." 


\subsection{Sanctus as a Consecration Prayer}

Mar Pinhas accompanies each stage of his tortures with a prayer (only in the Syriac, not in the Arabic epitome). Thus, immediately before dying he says (as McCollum translates): "You are holy, you are holy, mighty Lord, with whose praises both heavenly and earthly regions

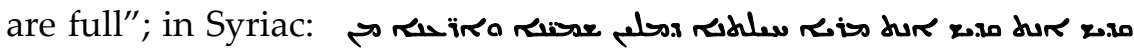
shwerd ( $\S 10$, p. 12/13 tr./txt). This is a paraphrase of Is 6:3, which is read in Peshitta as mbiesh r. where rudew corresponding to kúgtos $\Sigma \alpha \beta \alpha \omega \theta$ of LXX and to

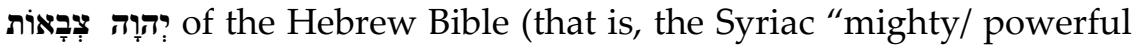
Lord" has the meaning of "Lord of (heavenly) Powers").

The most important difference between the biblical sentence and that of Mar Pinhas is the mention of heaven. This reveals the source of the quotation, which is not the Bible but a liturgical tradition, a form of the Sanctus from a consecration rite. Similar forms of the Sanctus (which contain "heaven and earth" instead of "earth" alone) are traceable back to the fourth or even third centuries but, probably, are even earlier. ${ }^{6}$

In Syriac, it is difficult to trace the history of the formula of the Sanctus because it is normally abbreviated in the liturgical manuscripts $^{7}$ and only seldom appears written down in full.The earliest attestation is probably the Syriac fourth-century History of John, the Son of Zebedee (CANT 222). ${ }^{8}$ In the Syriac text, the formula appears in full twice (in Arabic only once, probably due to an abbreviation at the

(6) B. D. SPINKs, The Sanctus in the Eucharistic Prayer, Cambridge, 1991 [pbk 2002], pp. 116-121. Nevertheless, the adjective forms in our text (ع) instead of the corresponding nouns are quite unusual. For current scholarship on the Sanctus, s. M. E. JOHNSON, "Recent Research on the Anaphoral Sanctus: An Update and Hypothesis," in: Issues in Eucharistic Praying in East and West. Essays in Liturgical and Theological Analysis, ed. by M. E. JOHNSON, Collegeville, MN, 2011, pp. 161-188. One of the earliest witnesses in Greek is Apostolic Constitutions VIII, 12, 27 (4th cent.): A $\gamma$ เos, \& $\alpha \gamma \operatorname{tos}$,

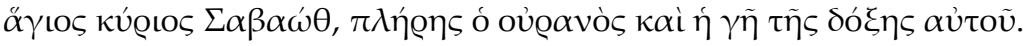

(7) E. g., one can check the manuscripts used in the series Anaphorae Syriacae.

(8) This will be quoted (p. txt/tr.) according to the following editions: Syriac original W. WRIGHT, Apocryphal Acts of Apostles, Edited from Syriac Manuscripts in the British Museum, vol. I: Syriac Texts; vol. II: English Translation, London, Edinburgh, 1871; Arabic version: A. SMITH LEWIS, Acta Mythologica Apostolorum, London, 1904. 


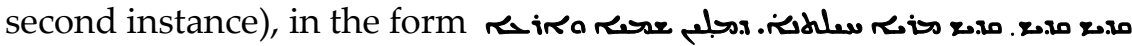
mbined ("Holy, Holy, Holy (is) the Lord Almighty, of whose praises

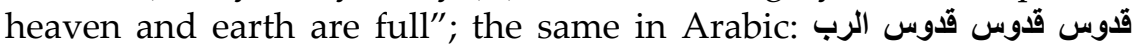
القدر الذى السما9 والارض مملوة من تسبحته of the heavenly liturgy (p. حه/23; Arabic: p. 1 \&0/163), and at the second instance, it is a vision of the consecration of the chrismation oil (p. $\downarrow / 54^{10}$ ) Almost the same form of the sentence became standard for different Syriac liturgies (with one difference: the preposition $\rightarrow$ is added before mhines). ${ }^{11}$

One can see that, indeed, Mar Pinhas' Sanctus does not coincide with any of the known variants but it nevertheless retains a distinctive liturgical mark, theaddition of "heaven." The wording "holy art Thou" (aur ع.6), with a copula, is unusual in the liturgical Sanctus but occurs otherwise in Syriac liturgical texts, including the acclamation of the priest, deacons, and people at the very beginning of the Liturgy of the Word, just before the Pater. Moreover, among the East Syrian canons (a sort of troparia accompanying the Eucharistic anaphora and variable according to the liturgical calendar), those of the Epiphany andEaster contain the acclamation "Holy art Thou, holy art Thou,

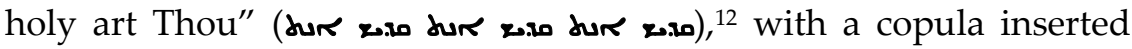
exactly in the same manner as in our phrase by Mar Pinhas. In Mar Pinhas' phrase, the third "Holy art Thou" is lacking but this is, most probably, an abbreviation - quite usual in Syriac liturgical manu-

(9) Pro السماء.

(10) For the Syrian fourth-fifth century baptismal liturgy in this text, s. A. F. J. KLIJN, "An Ancient Syriac Baptismal Liturgy in the Syriac Acts of John," NT, 6 (1963), pp. 216-228.

(11) E.g., L. NAMATO, The Order of the Holy Qurbana according to the Liturgy of Mar Addai and Mar Mari, the Blessed Apostles (for the Use of the Faithful), San Jose, CA, 2004, p. 50.

(12) Liturgia sanctorum apostolorum Adaei et Maris. Cui accedunt duae aliae in quibusdam festis et feriis dicendae: necnon ordo baptismi, Urmiae, 1890, p. Tr.: K. A. PAul, G. MooKen, The Liturgy of the Holy Apostles Adai and Mari, together with 2 additional liturgies to be said on certain feasts and other days, and the Order of Baptism. Complete and entire; collated from many MSS. from various places, Piscataway, NJ, 2002 [repr. of 1893 edition], p. 60. 
scripts $^{13}$ - rather than a real distinction; alternatively, it could be a result of a lapsus calami.

Thus, despite its peculiar form, the Sanctus of Mar Pinhas remains within the limits of the Syriac liturgical phraseology.

The most interesting element is the meaning of the Sanctus in our hagiographical text. As is known, the fourth-century Antiochene tradition inherited by both "Nestorians" and "Monophysites" considers this moment of the anaphora as the moment of the consecration of the Holy Gifts, whereas the epiclesis is considered as the moment of their transformation into the resurrected body of Christ. The implied distinction between the sacrificed and resurrected bodies of Christ resulted in the known weakness of Severus of Antioch's own attitude in his polemics against Julian of Halicarnassus, ${ }^{14}$ but evidently caused no problem for the Church of the East. Theodore of Mopsuestia says unambiguously that the Sanctus (which his Syriac translator quotes as

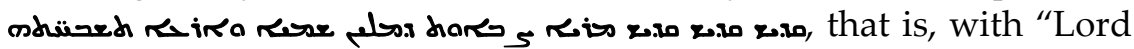
Sabaoth" instead of "Lord Almighty"), is the moment when "le pontife commence à offrir l'oblation et immole la sacrifice de la communauté." 15

\subsection{Fractio}

Mar Pinhus' Sanctus is recited, indeed, at the final scene of his tortures, immediately before his death. What follows is the fractio: immediately after these words of the Sanctus, "[t]he judge commanded, and they released him and put him on the ground, and they dismembered him with swords (حم:a). At this time, his soul departed joyfully from his body to his Lord..." (§ 10, p. 12/13). Such a dismembering of a martyr is not a commonplace in the hagiography.

(13) For "Holy art Thou" in the Sanctus written down twice instead of thrice, s., e. g., 298 (variant readings to line 11), where two mss and one 16thcent. printed edition are indicated.

(14) В. М. Аурье [B. LOURiÉ], История византийской философии. Формаmuвныŭ nepuod [B. LOURIÉ, The History of the Byzantine Philosophy. The Formative Period], Санкт-Петербург, 2006, с. 187-189.

(15) Homily XVI, the commented text and §§ 5-9; Théodore de Mopsueste, Les homélies catéchétiques. Reproduction phototypique du ms. Mingana syr. 561 (Selly Oak Colleges' Library, Birmingham), éd. R. TONNEAU, R. DeVREESSE (Studi e testi, 145), Città del Vaticano, 1949, pp. 531-533, 541-549. This homily develops the whole conception of the consecration and immolation at the Sanctus and the resurrection at the epiclesis. 
This direct passage from the Sanctus to the fractio requires comment.

The epiclesis, whose expected place is between the Sanctus and the fractio, is clearly absent. Indeed, if the epiclesis is, according to the Antiochene tradition, the prayer of resurrection, it must be out of place in our case. Unlike Christ, Mar Pinhas was not resurrected. Any pre-communion prayers would also be out of place.

The same consideration is not applicable to the Institution Narrative, however. It would have been easy to have added a scene with a prayer referring to Jesus' institutional words. The lack of such a scene after the Sanctus is a mark of a liturgical tradition in which the anaphora did not contain the Institution Narrative, such as the Eastern Syrian Anaphora of Addai and Mari. This fact hints at the direction in which we must look for other elements of the liturgical tradition involved: the East Syrian rite - which is to be expected given the East Syrian provenance of The Story of Mar Pinhas.

In the East Syrian rite, however, one must expect, after the Sanctus, the Intercessio, which is apparently also lacking from our text. However, the real situation of the Intercession in our text is more complicated and will be discussed below.

\subsection{Inconsistent Editing}

The account of Mar Pinhas' tortures contains inconsistencies that betray a somewhat difficult editorial history. The actual story runs as follows. The judge, after having heard Mar Pinhas' Christian confession, "commanded his tongue to be cut out with a sword (حمa) and his flesh to be lacerated with a saw" - something similar to but not exactly the same as the final scene of the martyrdom that we have interpreted above as fractio (the Syriac word used for "sword" is the same, although areal sword would not be especially fit for cutting tongues ${ }^{16}$ ). The mention of a saw corresponds to the list of torture instruments prepared by the judge at the very beginning: "blades, combs, wedges, saws, nails, and all the craft of Satan." One can see

(16) Other possible translations of this word are "sabre" and even "knife (for circumcision)"; cf. R. MURRAY, "Circumcision of Heart' and the Origins of the Qyāmâ," in After Bardaisan. Studies on Continuity and Change in Syriac Christianity in Honour of Professor Han J. W. Drijvers, ed. G. J. REININK, A. C. KLUGKIST (Orientalia Lovaniensia Analecta, 89), Leuven, 1999, pp. 201211, with following bibliography. 
that laceration with a saw would not result in a dismembering equal to that of the fractio.

No such dismemberment has been carried out, however. The martyr will remain fluently and readily speaking until his death. Instead, the person who betrayed Mar Pinḥas to the judge, Aniha, asked: "Sir, give me the friend of the Christians, and I will give him a severe beating." The judge answered: "Go on and give him a severe beating..." (§ 8, p. 10/11). This has not been carried out either - at least, in the current recension of the text. Instead, Aniha tried to burn Mar Pinhas but without success; this scene ends with the invective of Mar Pinhas directed to some "wicked" person addressed as "you" (§ 9, p. 10/11). It turns out that this person is now the judge: "When the judge heard these things..." Aniha disappears without a trace, the rest of the tortures being resumed by the judge ( $§ 10$, p. 12/13).

These evident inconsistencies in the text could be interpreted as either the result of the shortening of a more complicated story or simply as an inaccurate superposition of two different accounts. Both variants would be compatible with the function of a foundation legend. In the second case, however, the liturgical interpretation of the martyrdom must be considered as a later editorial intervention. Be that as it may, we are interested in the liturgical interpretation as it is currently present in the available text. Thus, in the following discussion, we will ignore the never-accomplished acts: cutting of the tongue, laceration with a saw, and, probably, "severe beating."

\subsection{The Opening Part of the Liturgy}

We have considered above the sections of the "liturgy" of Mar Pinhas that correspond to the consecration and the fraction. The preceding account is clearly divided into three parts: the initial section, the attempt to burn the martyr undertaken by Aniha, and the shooting by archers, also unsuccessful, led by the judge.

The opening scene runs as follows $(\S 8, \mathrm{p} .10 / 11)$. The judge shows Mar Pinhas the instruments of torture but the martyr is not afraid. He pronounces before the judge a phrase with a clear liturgical meaning - and, after that, the judge becomes irritated (what follows is the dialogue between the judge and Aniha quoted above). Mar Pinhas' liturgical phrase is: "Glory to your holy name, Father, Son, and Holy

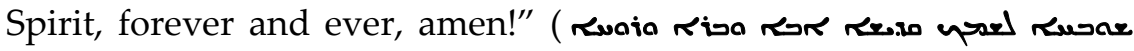

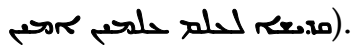


The opening verse referring to the name of God is a very rare feature that, as far as we know at the present time, occurs nowhere in the East Syrian rite. It is preserved, however, in the Maronite Anaphora of Peter III (also called Sharar "Confirm" according to the first word of its first prayer). ${ }^{17}$ The core of that Maronite anaphora is shared with the Eastern anaphora of Addai and Mari, and it thus could be used as a witness of an earlier shape of some liturgical units of this Eastern anaphora.

The Maronite Sharar, as it is currently known, contains an introductory section, but after this, the manuscripts insert the rubric "Et incipit <SC., the celebrant> anaphoram Petri Apostoli ( Rinasra Rivso ruele ooifar)" (p. 298/299). It is at this point that the section to be compared with our text begins. The opening verse of the proper part of the Sharar is "Glory to you, the adorable and glorious Name of the Father and of the Son and of the Holy Spirit..."18

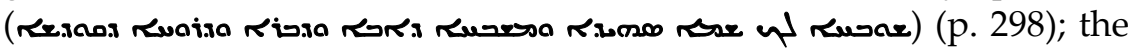
rest of this verse will be considered below. This verse is addressed directly to the name of God, whereas Mar Pinhas refers to the name of God in the context of addressing the Holy Trinity. In the Anaphora of Addai and Mari this verse is further "standardised" in a manner that avoids any addressing of the divine name. ${ }^{19}$ Both in the Sharar and in the Anaphora of Addai and Marithe corresponding words belong to the pre-Sanctus prayer, but only in the Sharar do they preserve the rubric marking the beginning of the anaphora itself.

We have to conclude that The Story of Mar Pinhas preserves, more or less, an authentic wording of the opening verse of a Eucharistic anaphora close to the common core of the Anaphora of Addai and Mari and the Sharar.

(17) J. M. Sauget, "Anaphora S. Petri Apostoli Tertia," in Anaphorae Syriacae, vol. II, fasc. 3, Roma, 1973, pp. 274-328.

(18) English tr. by S. Y. JAMMO, "The Anaphora of the Apostles Addai and Mari: A Study of Structure and Historical Background," OCP 68 (2002), pp. 5-35.

(19) Even in its earliest manuscript: W. F. MACOMBER, "The Oldest Known Text of the Anaphora of the Apostles Addai and Mari," OCP 32 (1966), pp. 335-371 (360/361 txt/tr.); cf. another critical edition, A. GELSTON, The Eucharistic Prayer of Addai and Mari, Oxford, 1992. 


\subsection{The Pre-Sanctus Prayer}

The next scene is Aniha's attempt to burn the martyr (§ 9, p. 10/11). When the attempt turned out to be unsuccessful, the martyr said: "Nothing can separate me from the love of Christ, my God" (cf. Rom 8:38-39). Such a phrase is a commonplace in the hagiography of martyrdom but not in the Eucharistic anaphoras. Given that all other words spoken by the martyr throughout the "liturgical" part of our text (§§ 8-10) are related to the Eucharistic prayers, this paraphrasing of Rom 8:38-39 could be a remnant of a previous "non-liturgical" edition. In any case, these words do not belong to the anaphora paraphrased in our story.

Aniha then demands once more that Mar Pinhas worship the idols. Mar Pinhas' answer is a recognisable paraphrase of a pre-Sanctus prayer ${ }^{20}$ close to those of the anaphoras of Addai and Mari ${ }^{21}$ and the Sharar, especially to the more succinct variant of the prayer provided by the Maronite text (s. Table 1). Mar Pinhas elaborates on the prayer's wording rather freely but without losing its core.

Table 1

\begin{tabular}{|c|c|c|}
\hline Mar Pinḥas & Sharar & Addai and Mari \\
\hline $\begin{array}{l}\text { Glory to your holy } \\
\text { name, Father, Son, } \\
\text { and Holy Spirit, for- } \\
\text { ever and ever, amen! } \\
<\ldots \text {..> How can I for- } \\
\text { sake the God who } \\
\text { made heaven and } \\
\text { earth, and all that is } \\
\text { in them, who sent his } \\
\text { beloved son to save } \\
\text { me and gave himself }\end{array}$ & $\begin{array}{l}\text { Glory to you, the } \\
\text { adorable and glorious } \\
\text { Name of the Father } \\
\text { and of the Son and of } \\
\text { the Holy Spirit, who } \\
\text { created the worlds by } \\
\text { his grace and its in- } \\
\text { habitants by his mer- } \\
\text { cy, and has effected } \\
\text { redemption toward } \\
\text { mortals by his grace. }\end{array}$ & $\begin{array}{l}\text { Worthy of praise } \\
\text { from every mouth } \\
\text { and thanksgiving } \\
\text { from every tongue } \\
\text { is the adorable and } \\
\text { glorious Name of the } \\
\text { Father and the Son } \\
\text { and the Holy Spirit, } \\
\text { who created the } \\
\text { world in his grace } \\
\text { and its inhabitants in }\end{array}$ \\
\hline
\end{tabular}

(20) More precisely, the first half of the answer. The rest of it is the following: "And he will come again in the end time with great and unspeakable glory, effecting resurrection and resuscitation for the whole human race: he will save the righteous for their righteousness, and the wicked, like you, he will cast into hell and the unquenchable fire!" This material is alien to the Eucharistic prayer but depends on the context of the martyrdom.

(21) English tr. from GELSTON, The Eucharistic Prayer, pp. 48-55. 


\begin{tabular}{|c|c|c|}
\hline $\begin{array}{l}\text { to death for our sake, } \\
\text { and saved us from } \\
\text { the bondage of Satan? }\end{array}$ & & $\begin{array}{l}\text { his loving-kindness, } \\
\text { and redeemed the } \\
\text { sons of men in his } \\
\text { mercy, and dealt very } \\
\text { graciously with mor- } \\
\text { tals. }\end{array}$ \\
\hline 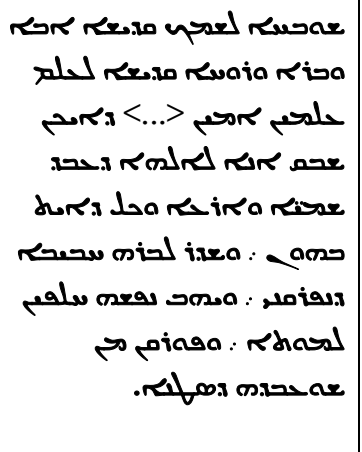 & 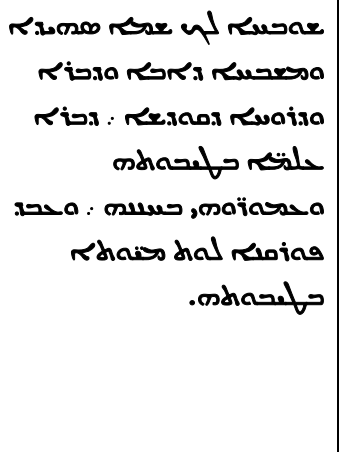 & 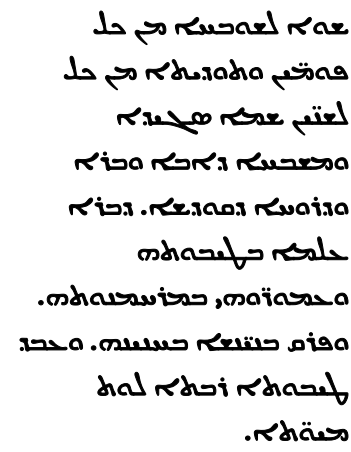 \\
\hline
\end{tabular}

\subsection{Pre-Anaphoral Rites}

Setting aside the tortures only mentioned in our text but never accomplished, the martyrdom as a whole is subdivided into three parts. The third one is discussed above ("fraction"), and the first two episodes represent an attempt to burn Mar Pinhas (§ 9, p. 10/11) and his shooting by seven archers (§10, p. 12/13).

The attempt to burn the martyr is described rather laconically: Aniha "...piled wood on top of him. He lit a fire on it, but the victorious one was not frightened: rather, he praised God and said, 'Nothing can separate me from the love of Christ, my God!'” The next scene, however, is quitevivid:

When the judge heard these things, he took the fetters and chains of bronze and he bound his arms and neck and tossed him head first over a high cliff. The victorious Mar Pinhas said, "I confess the Father, Son, and Holy Spirit!" When the judge heard him, he commanded him to be pierced with sharp arrows. Then he set up seven archers and they were mercilessly shooting arrows and casting stones at him, while he was hanging upside down on the high cliff, and with the praise of God and the hymns he was continuously offering up not ceasing from his mouth, saying, "You are holy..." [what follows is the Sanctus section, which has already been discussed]. 
Such episodes are clearly symbolic and, given the liturgical shape of the elements of the account already discussed, it is to be expected that this symbolism turns out to be liturgical as well. Indeed, in the East Syrian rite, we have the preparation rites preserved as part of the public service, without losing their solemn appearance. Thus, we have to recall the rites of preparation of the liturgical bread and wine.

In the East Syrian rite, the bread must be prepared shortly before the liturgy and it is to be used while still warm. The procession moves from the oven to the prothesis near the altar; no prayer is to be read (the offering prayer will be recited at the pre-anaphoral part of the Eucharistic liturgy itself). ${ }^{22}$ In the case of Mar Pinhas, we also see a rite of "baking" without any accompanying prayer but within a public ceremony. It correlates, moreover, with the subsequent scene, which is to be interpreted as a symbolic representation of the preparation of the wine.

The martyr is exposed when hanging onto a height: this scene clearly alludes to the culmination of the preparation rites in the East Syrian Eucharistic liturgy, which is postponed until the final part of the Liturgy of the Word, after the readings and immediately before the Creed and the diaconal intercession prayers. "[T]he priest takes the chalice in his right hand, and the paten in his left hand, while crossing his hands," and lifts both of them. ${ }^{23}$

The posture of the martyr who was hanging upside down alludes to the grape hanging on the vine. The grape is pierced in order to extract the wine. In the East Syrian rite, the wine is to be poured into the chalice before the Liturgy of the Word, after the preparation of

(22) S., with a historical and comparative approach, P.-E. GEMAYEL, Avant-messe maronite. Histoire et structure (OCA, 174), Roma, 1965, p. 273.

(23) The quotation is from the corresponding rubric of the current rite of the East Syrian Eucharistic liturgy; the accompanying prayer begins with the words "Let us lift up praise to your glorious Trinity always and forever" (NAMATO, The Order of the Holy Qurbana, p. 31; the exact wording of this prayer varies according to the mss but without changing the general meaning, cf. the critical editions). For the description of the liturgical gesture, s., е. g., СОФОНІя [СОКОльскій], епископъ Туркестанскій, Современный быть и литургія христіань инославныхь Іаковитовь и Несторіань... [SOFONIJA $<$ SOKOL'SKIJ>, bishop of Turkestan, Contemporary Life and the Liturgy of the Non-Orthodox Christian Jacobites and Nestorians...], Санкт-Петербург, 1876, c. 358, as well as S. Y. H. JAMMO, La structure de la messe chaldéenne du début jusqu'à l'anaphore. Étude historique (OCA, 207), Rome, 1979, pp. 161-162. 
the bread on the paten. The accompanying words vary according to the available sources but they normally allude to the piercing of Christ's side with a lance. ${ }^{24}$

The symbolism of the number of archers, seven, is striking but apparently unclear: it does not correspond to anything in the East Syrian rite as it is described in the preserved documents. However, it does have a correspondence in the Maronite rite, which has common roots with the East Syrian one. In sixteenth-century Maronite manuscripts, the diaconal intercession prayers at the final part of the Liturgy of the Word normally include several (from two to four) long hymns with various commemorations and intercessions, each of them having seven strophes. ${ }^{25}$ This is clearly a later elaboration but it has some basis in an earlier rite, where the sevenfold structure of the diaconal commemoration and intercession at the end of the Liturgy of the Word was already established.

It would be reasonable to conclude that the number of archers seven - alludes to the sevenfold structure of the commemoration/intercession prayers at the end of the Liturgy of the Word. This part of the Liturgy of the Word in the East Syrian rite has a rather unclear history. ${ }^{26}$ It presents a mixture of different rogations distributed between the two similar kinds of synapte, $b \bar{a} ' \bar{u} t \bar{a}$ (حr) and kārōzūtā (rhaiv). The ancient commentators Pseudo-Narsai (sixth cent. ${ }^{27}$ ) and Gabriel Qatraya Bar Lipeh (ca 615) provide very vague

(24) Thus, in the late 19th-cent. ritual published by the Anglican mission in 1892, the words are: "One of the soldiers with a spear pierced the side of our Lord and forthwith came there out blood and water..." (tr.: F. E. BRIGHTMAN, Liturgies Eastern and Western, vol. I: Eastern Liturgies, Oxford, 1896, pp. 251-252; the original publication was unavailable to me; s. also JAMMO, La structure, p. 168). This agrees with the present-day custom of the Syrian Orthodox and mediaeval manuscripts of the Maronites (GEMAYEL, Avantmesse maronite, p. 275). Sofonija of Turkestan (Современный быть и литургія, c. 346-347) provides a more elaborated wording, separately for the wine and the water, but alluding to the same Gospel scene in both cases.

(25) GEMAYEL, Avant-messe maronite, pp. 94-97. These hymns have seven strophes as a rule, although there are some rare exceptions where there are fewer strophes (i. e., four).

(26) JAMMO, La structure, p. 147, cf. pp. 139-150.

(27) S., on his homily XVII according to Mingana's 1905 edition (with previous bibliography), L. ABRAMOWSKI, "Die liturgische Homilie des Ps. Narses mit dem Messbekenntnis und einem Theodor-Zitat," Bulletin of the John Rylands Library, 78 (1996), pp. 87-100. 
descriptions that do not permit an evaluation of the number of groups into which these numerous petitions were distributed. Hopefully, our Story of Mar Pinhas will contribute to a further exploration of this problem.

The identification of the seven archers as symbols of a sevenfold intercession would also explain why the anaphoral intercessio is lacking between the Sanctus and the fractio. The frame of the symbolism of martyrdom is too narrow for the two analogous intercessions of the liturgy, and this is why only one of them has been kept for symbolic representation.

Finally, the words of Mar Pinhas "I confess the Father, Son, and Holy Spirit!" are also explained within the liturgical context. This exclamation is placed within the episode that, as we have already seen, agglomerates the preparation of the chalice, the lifting of the paten and the chalice by the priest, and the diaconal commemoration/intercession prayers. Thus, in the East Syrian rite as it is described already in Pseudo-Narsai, these words uttered by Mar Pinhas correspond to the Nicene Creed, which is to be recited just after the diaconal intercessions. The words of Mar Pinhas serve as a summary of the Creed.

\subsection{Conclusion: the Liturgy of Mar Pinḥas}

Now we are in a position to summarise our liturgical analysis. The elements of the East Syrian Eucharistic liturgy are represented in the symbolism of Mar Pinhas' martyrdom in a compressed form, in which the preparatory elements of the rite are embedded within the central elements of the East Syrian anaphora, that is, near the Sanctus. These central elements, which form the liturgical core of the act of martyrdom, are the following:

1. The opening verse of the anaphora sensu proprio (now best preserved in the Maronite anaphora Sharar) invoking the Name of God

2. The pre-Sanctus prayer

3. The Sanctus

4. The fractio, which is added at the end of this scheme.

The Institution Narrative is lacking in the anaphora taken as the prototype (which was, most probably, that of Addai and Mari). The epiclesis is absent because its meaning (according to the Syrian/ Antiochene tradition as a whole) is the resurrection, which does not 
fit with the plot of martyrdom. The intercession part of the anaphora is also lacking, because it is the first (pre-anaphoral) intercession that is chosen for symbolic representation.

The preparation and other pre-anaphoral rites are superposed onto the above scheme in the following way:

1a. Preparation of the liturgical bread

2a. Preparation of the liturgical wine

$2 \mathrm{~b}$. Lifting of the species by the priest

2c. Intercessions

2d. Creed.

The elements enumerated from $2 \mathrm{a}$ to $2 \mathrm{~d}$ are "telescoped" into one scene, without regard for their proper sequence. The resulting scheme (s. Table 2) is also a product of the "telescoping" of preanaphoral and anaphoral elements.

Table 2

\begin{tabular}{|c|c|c|c|}
\hline $\begin{array}{l}\text { Anaphoral } \\
\text { elements }\end{array}$ & $\begin{array}{l}\text { Pre- } \\
\text { anaphoral } \\
\text { elements }\end{array}$ & $\begin{array}{l}\text { Episodes of } \\
\text { the Martyrdom }\end{array}$ & $\begin{array}{l}\text { The Closest } \\
\text { Liturgical } \\
\text { Evidence }\end{array}$ \\
\hline \multirow[t]{2}{*}{$\begin{array}{l}\text { 1. Opening } \\
\text { verse of the } \\
\text { anaphora. }\end{array}$} & & $\begin{array}{l}\text { Glory to your } \\
\text { holy name, Fa- } \\
\text { ther, Son, and } \\
\text { Holy Spirit, for- } \\
\text { ever and ever, } \\
\text { amen! }\end{array}$ & $\begin{array}{l}\text { Opening verse of } \\
\text { the Maronite } \\
\text { anaphora Sharar } \\
\text { (s. } \S 3.5 \text { above). }\end{array}$ \\
\hline & $\begin{array}{l}\text { 1a. Prepara- } \\
\text { tion of the } \\
\text { liturgical } \\
\text { bread. }\end{array}$ & $\begin{array}{l}\text { Aniha tries to } \\
\text { burn the martyr. }\end{array}$ & $\begin{array}{l}\text { East Syrian rite of } \\
\text { procession from } \\
\text { the oven to the } \\
\text { prothesis. }\end{array}$ \\
\hline \multirow[t]{2}{*}{$\begin{array}{l}\text { 2. Pre-Sanctus } \\
\text { prayer. }\end{array}$} & & $\begin{array}{l}\text { Martyr's answer } \\
\text { to Aniha. }\end{array}$ & $\begin{array}{l}\text { Pre-Sanctus pray- } \\
\text { er of the Sharar } \\
\text { (s. Table } 1 \text { above). }\end{array}$ \\
\hline & $\begin{array}{l}\text { 2a. Prepara- } \\
\text { tion of the } \\
\text { liturgical } \\
\text { wine. }\end{array}$ & $\begin{array}{l}\text { The archers shoot } \\
\text { the arrows at the } \\
\text { martyr. }\end{array}$ & $\begin{array}{l}\text { The words ac- } \\
\text { companying the } \\
\text { pouring of the } \\
\text { wine (and/or } \\
\text { water) into the } \\
\text { chalice in various }\end{array}$ \\
\hline
\end{tabular}




\begin{tabular}{|c|c|c|c|}
\hline & & & $\begin{array}{l}\text { Syrian rites, } \\
\text { which allude to } \\
\text { the piercing of } \\
\text { Jesus' side with a } \\
\text { lance. }\end{array}$ \\
\hline & $\begin{array}{l}2 \mathrm{~b} \text {. Lifting of } \\
\text { the paten and } \\
\text { the chalice by } \\
\text { the priest. }\end{array}$ & $\begin{array}{l}\text { The martyr hangs } \\
\text { upside down on } \\
\text { the high cliff } \\
\text { (which posture } \\
\text { alludes to the } \\
\text { grape of the } \\
\text { vine). }\end{array}$ & $\begin{array}{l}\text { The liturgical } \\
\text { gesture common } \\
\text { to the East Syrian } \\
\text { and some other } \\
\text { Syrian rites. }\end{array}$ \\
\hline & $\begin{array}{l}\text { 2c. Diaconal } \\
\text { intercessions. }\end{array}$ & $\begin{array}{l}\text { The number of } \\
\text { archers is seven. }\end{array}$ & $\begin{array}{l}\text { Some form of } \\
\text { sevenfold inter- } \\
\text { cession, which } \\
\text { must be the ulti- } \\
\text { mate structural } \\
\text { matrix of the } \\
\text { mediaeval } \\
\text { Maronite seven- } \\
\text { strophe diaconal } \\
\text { intercession } \\
\text { hymns. }\end{array}$ \\
\hline & 2d. Creed. & $\begin{array}{l}\text { Reduced to "I } \\
\text { confess the Fa- } \\
\text { ther, Son, and } \\
\text { Holy Spirit!" }\end{array}$ & \\
\hline 3. Sanctus & & $\begin{array}{l}\text { "You are holy, } \\
\text { you are holy, } \\
\text { mighty Lord, } \\
\text { with whose } \\
\text { praises both } \\
\text { heavenly and } \\
\text { earthly regions } \\
\text { are full!" }\end{array}$ & $\begin{array}{l}\text { Rewordings of } \\
\text { the Sanctus in the } \\
\text { East Syrian hym- } \\
\text { nography within } \\
\text { the anaphora } \\
\text { (canons). }\end{array}$ \\
\hline 4. Fractio & & $\begin{array}{l}\text { The martyr is } \\
\text { dismembered by } \\
\text { swords. }\end{array}$ & \\
\hline
\end{tabular}




\section{ANTi-JeWish Polemics?}

As allegedly a martyr under King Shapur, Mar Pinhas is presumed to die at the hands of the Zoroastrians. But are there any Zoroastrians among the characters of the Story? There are indeed, or, at the least, there is one Zoroastrian on the stage, but the plot only tangentially touches on his Zoroastrianism.

This is Mar Pinhas' judge, Simun (ספר ה of Panak, in the area in which Mar Pinhas lived; he apparently bears an Iranian name (McCollum compares it with such Iranian names as Simo, Simas, and Simos); the city of Panak is located in the Cizre region, about $12 \mathrm{~km}$ northeast of Cizre (s. McCollum commentaries, p. 22). In an answer to Simun, Mar Pinhas refuses to worship the sun (§ 7, p. 8/9), which may be - but is not necessarily (s. below) - an indication of a Zoroastrian context. Simun is declared to be a relative of King Shapur (§ 4, p. 6/7), and so he must be a Zoroastrian.

However, if he is a Zoroastrian, it is to be expected that he will behave as a Zoroastrian - but he does not. He addresses the martyr with the following demand: "Let go ofthe error you're holding on to, and worship the seventy-two gods with us! ( "( (\$ 6, p. 8/9). It is this demand that Mar Pinhas answered with a refusal to worship the sun. "The seventy-two gods" are not mentioned in any other place throughout the remainder of the text. The inconsistency of the Story at this point is blatant and could be explained as either a later editorial intervention or, better, a mark of the approach taken by the original author, whose narrative could absorb rather mechanically parts of different sources.

To explain these "seventy-two gods," McCollum proposes two hypotheses: the number seventy-two could either represent the seventy-two chapters of the Yasna, which are, in turn, represented with seventy-two strands of the Zoroastrian sacred girdle Kushti, or "some concept of this number of divine or divinely created entities, as in the text from Nag Hammadi conventionally called On the Origin of the World;" ${ }^{28}$ he calls the second possibility "more remote" (p. 23).

(28) He refers to the critical edition and the translation of this tractate Nr 5 from the Nag Hammadi codex II: B. LEYTON, Nag Hammadi Codex II, 2-7, together with XIII, 2*, Brit. Lib. Or.4926(1), and P.OXY. 1, 654, 655: with contributions by many scholars, vol. 2, Leiden, 1989, 45 (Engl. tr.; cf., for the Coptic text, p. 44). 
I think that, in fact, it is with the second possibility that McCollum hints at the correct path. Indeed, Egyptian Gnosticism would hardly have any direct relation to Syriac hagiography in Iran, but the text pointed out by McCollum ${ }^{29}$ is heavily dependent on the Jewish mystical tradition, especially the part dealing with the seventy-two gods: their Jewish counterparts are evidently the seventy-two names of the Metatron, which also - in the same manner as in the Egyptian tractate - correspond to the seventy-two nations. ${ }^{30}$ These names were easily interpretable in a polytheistic manner, either by Egyptian heathens or by some monotheistic opponents of the Jewish Merkabah and/or Hekhalot mysticism. A well-known and widespread motive of the early Christian (that is, from the $2^{\text {nd }}$ to the $4^{\text {th }}$ cent., starting from Aristides) anti-Jewish polemics is interpretation of the Jewish services as directed to the angels instead of to God. ${ }^{31}$ In the face of Hekhalot

(29) The Coptic text itself sounds very "Jewish." I quote it here to unpack McCollum's unreferenced quotation, although the same motives could be read in a variety of properly Jewish mystical texts: "And before his [Sabaoth's] mansion he created a throne, which was huge and was upon a four-faced chariot called 'Cherubin'. Now the Cherubin has eight shapes per each of the four corners, lion forms and calf forms and human forms and eagle forms, so that all the forms amount to sixty-four forms - and seven archangels that stand before it; he is the eighth, and has authority. All the forms amount to seventy-two. Furthermore, from this chariot the seventytwo gods took shape; they took shape so that they might rule over the seventy-two languages of the peoples. And by that throne he created other, serpent-like angels, called 'Seraphin', which praise him at all times" (Leyton's tr., ibid.).

(30) On the mystical tradition related to the "lesser God" Metatron, still within the unique God, and his seventy or seventy-two names which are divine names able to act each in its proper fashion, s., first of all: J. DAN, "The Seventy Names of Metatron," in Proceedings of the World Congress of Jewish Studies. Division C: Talmud and Midrash, Philosophy and Mysticism, Hebrew and Yiddish Literature, Jerusalem, 1981, pp. 19-23; K. E. GRÖZINGER, “The names of God and the celestial powers: their function and meaning in the Hekhalot literature," Jerusalem Studies in Jewish Thought, 6 (1987), 1-2, pp. 53-69, and, especially, for a theological interpretation, J. E. Fossum, The Name of God and the Angel of the Lord. Samaritan and Jewish Concepts of Intermediation and the Origin of Gnosticism (WUNT, 36), Tübingen, 1985; s. also recent bibliography below, fn. 32 .

(31) D. D. HANNAH, Michael and Christ: Michael Traditions and Angel Christology in Early Christianity (WUNT, 2/109), Tübingen, 1999, pp. 106-109. 
mysticism, this polemical tradition would evolve into a charge of polytheism.

We now know that the origin of the Metatron tradition predates the Hekhalot literature by several centuries and goes back, most probably, to first-century AD Palestine or Egypt, ${ }^{32}$ but this conclusion does not affect substantially Peter Schäfer's argument in favour of the later Babylonian origin of the Hekhalot tradition sensu proprio; ${ }^{33}$ moreover, the exact number of the names of the Metatron, 70 or 72 , is not attested before the Sefer Hekhalot (also known as 3 Enoch), whose date is uncertain but posterior to the first century AD.

The exact geography of the Hekhalot mysticism within the Jewish Babylonian diaspora is, of course, unknown. However, we do know that the region of Cizre, which is located near Mt Ğudi (Turkish Cudi, Arabic الجودي), Syriac Mt Qardu, مi:a) - associated by the Syrians and by the majority of Muslim scholars with the resting place of Noah's Ark (as it is named in Quran 11:44) - had a large and longestablished Jewish population already in the twelfth century (when it was first described by the Jewish travellers Benjamin of Tudela and Petahya of Ratisbonne) ${ }^{34}$ The area was a very suitable place for developing tensions or conflicts between the Eastern Syrian ("Nestori-

(32) A. ORLOV, The Enoch-Metatron Tradition (TSAJ, 107), Tübingen, 2005; B. LOURIÉ, "One hapax legomenon and the Date of 2 Enoch," Enoch, 33 (2011), pp. 94-96; C. H. T. FletCHER-LOUIS, "2 Enoch and the New Perspective on Apocalyptic," in: New Perspectives on 2 Enoch. No Longer Slavonic Only, ed. by A. A. Orlov, G. BoccaccinI, J. M. ZuraWSKI (Studia Judaeoslavica, 4), Leiden, Boston, 2012, pp. 127-148 (135-143). As to the number of the names of Metatron, 70 or 72 , they belong to very similar and almost identical traditions, because Metatron's name in divinis, "Youth," and such names of God as the Tetragrammaton could be counted in addition to the number seventy; both 70 and 72 are symbolic ("round") values used within the same texts together. Cf., e. g., Fossum, The Name of God, pp. 296-301.

(33) P. SCHÄFER, The Jewish Jesus. How Judaism and Christianity Shaped Each Other, Princeton, 2012, pp. 138-140; this paragraph entitled "Metatron in Babylonia" could be read as related to the early history of the corresponding Hekhalot tradition but not of the earlier tradition related to the Metatron uniquely.

(34) E. BRAUER, The Jews of Kurdistan, ed. by R. PATAI (Jewish Folklore and Anthropology Series), Detroit, 1993, pp. 38-39, 55-56; cf. also H. GAVISH, "Kurdistan, Jews of," in Encyclopedia of Jewish Folklore and Traditions, ed. by R. PATAI, H. BAR-ITZHAK, vol. 1, Armonk, NY, London, 2013, pp. 303-308. 
$\left.a^{\prime \prime}\right)$ Christians and the Jews somewhere in the seventh century or later, around the time of the composition of The Story of Mar Pinhas.

The hagiographical substrate referring to the fourth century provided a favourable ground for anti-Jewish polemics. In the authentic Syriac martyr acts of the fourth century, the deplorable role of the Jews in the persecutions of the Christians by the Zoroastrians was often emphasised. ${ }^{35}$ In the seventh century, these recollections were refreshed by the events of 614, when Jerusalem was temporarily captured by the Persians. ${ }^{36}$

Thus, the geographical situation of our story, taken into account together with "seventy-two" as the alleged number of gods, results in a compelling argument for acknowledging an anti-Jewish polemical context. I think that there are two other arguments which would make such a supposition the most plausible alternative. Let us consider them step by step. The first argument is not decisive but it makes a contribution to our cumulative argumentation as a whole; it relies on the source used for the "apologetic" fragments of our story. It can be shown that it is an ancient Christian apology, otherwise unknown, aimed at both Jews and heathens. Our second argument will go to the very heart of our story, its liturgical core: I hope to demonstrate that the liturgical meaning of the relics of Mar Pinhas could be best explained as an answer to a specific Jewish liturgy dedicated to Jewish martyrs which emerged within the tradition of the Hekhalot mysticism.

\section{An Early Christian Apology}

The scene of the interrogation of Mar Pinhas before the tortures contains two answers given by the martyr. One of them brings us to the

(35) Cf. R. W. Burgess, R. Mercier, "The Dates of the Martyrdom of Symeon bar Sabba'e and the 'Great Massacre'," AB, 117 (1999), pp. 9-66; A. H. BECKER, "Beyond the Spatial and Temporal Limes: Questioning the 'Parting of the Ways' Outside the Roman Empire," in: The Ways that Never Parted, ed. by A. H. BeCKer, A. YoshiKo ReED (TSAJ, 95), Tübingen, 2003, pp. 373-392.

(36) Cf. E. Horowitz, "'The Vengeance of the Jews Was Stronger than Their Avarice': Modern Historians and the Persian Conquest of Jerusalem in 614," Jewish Social Studies, N.S., 4 (1998), pp. 1-39. For a larger historical perspective, especially of the seventh cent., s., first of all, G. DAGRON, V. DÉROCHE, Juifs et chrétiens en Orient byzantine (Bilans de recherche, 5), Paris, 2010. 
pre-Nicene epoch almost immediately: "I worship and confess the Christ, my God, who is the true shepherd and the wise leader, the

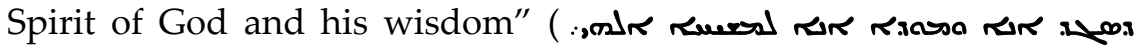
(\$ 5, p. 6/7). This claim only tangentially goes back to 1 Cor 1:24 (indicated by McCollum, p. 23) or to any

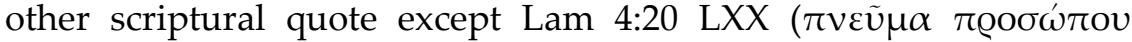

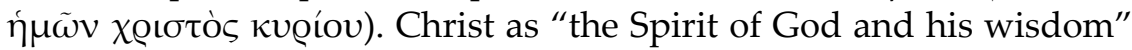
looks like the normative theology in the second century and reappears at some time later, but the best known Christian texts identifying Christ/Logos with the Spirit are the works of the second-century apologists. ${ }^{37}$ At any rate, such a formulation is scarcely imaginable in any post-Nicene theological text. It must be considered as a mark of an early origin for the quoted source. And this source was evidently an apology. Its anti-heathen stance is expressed straightforwardly in the following quotation $(\S 7$, p. $8 / 9)$, but a closer look at the same text would discern an anti-Jewish polemic as well:

How can I worship the sun, which darkened and mourned in gloom from the sixth to the ninth hour on the day Christ, my king and my God, suffered? Sometimes it's long and sometimes short, and it has no power over itself. But I worship the God of all: the one with power and a kingdom that never vanishes and has no end, the one whose chariot is cherubim, the one whom orders of watchers sanctify, the one whom all the ranks of flame worship. Get behind me, Satan, and your gods with you, off to the fire that will never go out, prepared for your father, the devil, and his angels!

The beginning of this reply has a rather close parallel in the secondcentury Apology of Aristide (CPG 1062), ch. VI according to the Syriac version $^{38}$ (s. Table 3):

(37) As an introduction to their "triadology", one can consult B. G. BUCUR, Angelomorphic Pneumatology: Clement of Alexandria and Other Early Christian Witnesses (Supplements to Vigiliae Christianae, 95), Leiden, Boston, 2009.

(38) J. R. HARRIS, The Apology of Aristides on Behalf of the Christians from a Syriac Ms. Preserved on Mount Sinai (Texts and Studies, I, 1), Cambridge, 21893, p. w/39 (txt/tr.). Cf. ibid., p. 103, the corresponding Greek text (preserved within the Romance on Barlaam and Joasaph and partially witnessed by

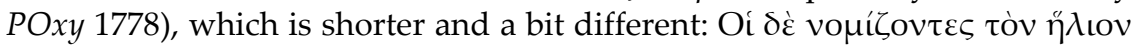

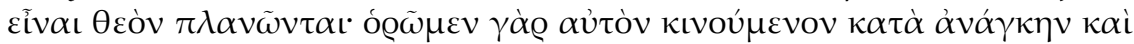

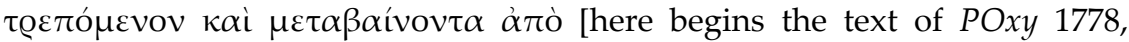

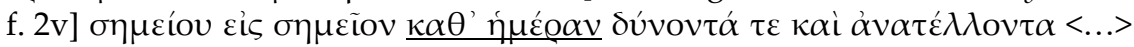




\section{Table 3}

\begin{tabular}{|c|c|}
\hline The Story of Mar Pinhas & Apology of Aristide \\
\hline $\begin{array}{l}\text { How can I worship the sun, which } \\
\text { darkened and mourned in gloom } \\
\text { from the sixth to the ninth hour } \\
\text { on the day Christ, my king and } \\
\text { my God, suffered? Sometimes it's } \\
\text { long and sometimes short, and it } \\
\text { has no power over itself. But I } \\
\text { worship the God of all: the one } \\
\text { with power and a kingdom that } \\
\text { never vanishes and has no end... }\end{array}$ & $\begin{array}{l}\text { So too those have erred who have } \\
\text { thought concerning the sun that } \\
\text { he is God. For lo! We see him, that } \\
\text { by the necessity of another he is } \\
\text { moved and turned and runs his } \\
\text { course; and he proceeds from } \\
\text { degree to degree [Gr. text: from } \\
\text { one sign (of the Zodiac) to anoth- } \\
\text { er], rising and setting every day } \\
<\ldots \text { and that not according to his } \\
\text { own will, but according to the will } \\
\text { of Him that ruleth him. }\end{array}$ \\
\hline 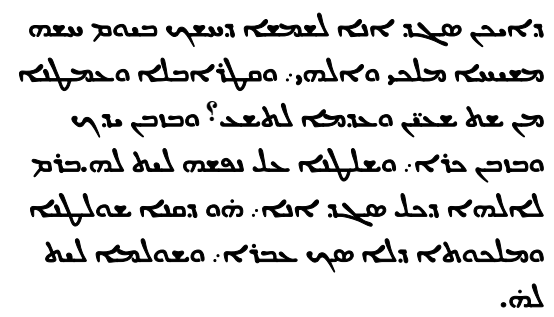 & 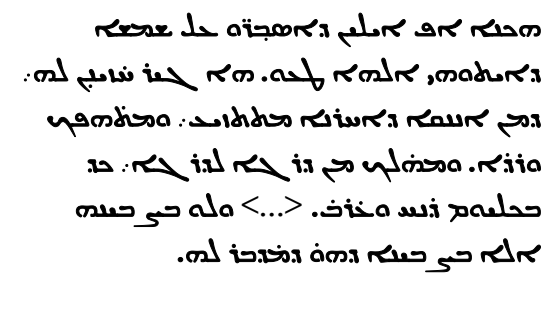 \\
\hline
\end{tabular}

The topic of this passage - that the sun is not God - is common to other apologies but, to my knowledge, the argumentation is rather peculiar. Moreover, Mar Pinhas' words "it has no power over itself" (m ded doractly to the words of the Greek

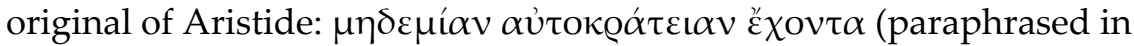
its Syriac version). Thus, Mar Pinhas' apologetical source shared some roots with the Apology of Aristide.

The continuation of Mar Pinhas' reply reveals imagery from Merkabah mysticism:

...the one whose chariot is cherubim, the one whom orders of watchers sanctify, the one whom all the ranks of flame worship.

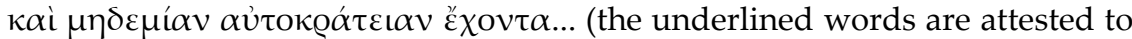
in the papyrus only). POxy 1778 is quoted according to C. WESSELy, "Les plus anciens monuments du christianisme écrits sur papyrus," Patrologia Orientalis, 18 (1924), pp. 500-502 (501). The Armenian version for this part of the Apology is not preserved. 


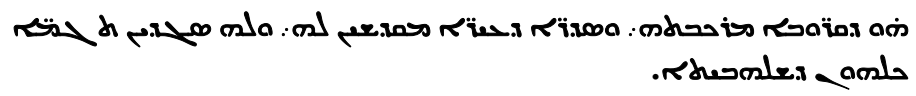

Such a digression about the Merkabah, the watchers (not an especially archaic term in Syriac), and "the ranks of flame" (another Ezekielian image of angels) would be out of place in an anti-heathen apology but would be especially welcome in an anti-Jewish context. Once more, we see in the Apology of Aristide some parallel with Mar Pinhas' apologetic source, because it was written - and this was unusual - against both heathens and Jews simultaneously. The case of Mar Pinhas' source is similar, but here, the theology of the Jewish opponents would imply some Merkabah mystic motives.

The first of Mar Pinhas' apologetic passages (§ 5, p. 6/7), whose opening we have quoted above, continues with a theological statement which provides another important mark of origin. The whole passage is as follows:

I worship and confess the Christ, my God, who is the true shepherd and the wise leader, the Spirit of God and his wisdom. He is first, middle, and last, and hisrule shall never and ever be dissolved. He will dissolve the earth and make it pass away according to his word and command: he is the existent one, forever and

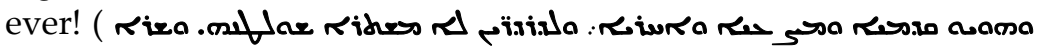

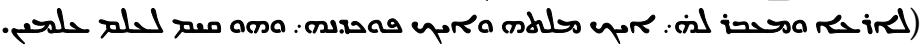

Mention of Christ/Logos as the beginning, the middle, and the end in a context mentioning the wisdom goes back to Wis 7:18, but, in the biblical text, this tripartite division is explicitly applied to the time, Christ/Logos is not mentioned, and the wisdom appears only as a teacher of the Wise. Gregory of Nyssa in his anti-Eunomian polemics often applied Wis 7:18 to the divine Wisdom-Logos, ${ }^{39}$ apparently following some established exegetical tradition authoritative in both his and in the Arians' eyes. There is, however, an ancient text showing a more specific affinity with the citation above, a secondcentury homily already known by its archaic Jewish-Christian features. ${ }^{40}$

(39) Contra Eunomium 3:6:67-71; Gregorii Nysseni Opera, vol. II: Contra Eunomium libri. Liber III, ed. W. JAEGER, Leiden, 1960, pp. 209-211.

(40) Homélies pascales. I. Une homélie inspirée du traité sur la Pâque d'Hippolyte, ed. by P. NAUTIN (SC, 27), Paris, 1950; for the bibliography of the scholarship following this publication, s. G. DRAGOŞ-ANDREI, "Pseudo-Hippolytus' In sanctum Pascha. A Mystery Apocalypse," in: Apocalyptic Thought 
In this homily, Christ is the shepherd who became the lamb

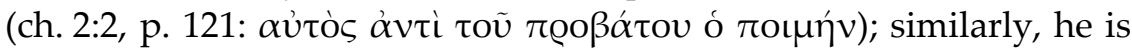
"the true shepherd" in Mar Pinhas. As the Passover lamb, Christ is described via the liturgical symbolism of the sacrifice. Thus, his head, entrails, and feet are the symbols of him as the beginning, the middle,

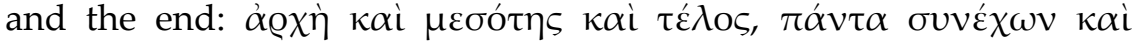

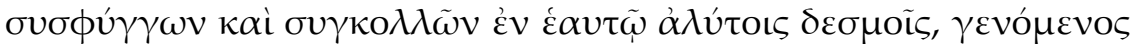

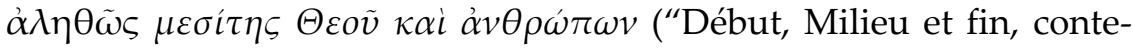
nant, asserant et assemblant tout, devenu vraiment Médiateur de Dieu et des hommes (1 Tim 2:5)") (ch. 29:3, pp. 154/155 tr./txt). Mar Pinhas' words "He is first, middle, and last, and his rule shall never and ever be dissolved" reveals the same link, within a unique sentence, between Christ as the beginning, the middle, and the end and the indissolubility of the world order established by him. This similarity is specific enough to conclude that both homily and Mar Pinhas share the same theological tradition. This tradition was not only exegetical but also liturgical - in the sense that it contained a Christian explanation of the symbolic meaning of the Old Testament Passover sacrifice.

Thus, such features as "pneumatological Christology" and shared motives with the Apology of Aristides and a second-century homily point in the same direction: a second-century apologetic source directed against both heathens and Jews.Mar Pinhas quotes this archaic material in the same manner as Barlaam in the Barlaam and Joasaph quotes the Apology of Aristides.

\section{ATONEMENT Via A MARTYR: MAR PINḤAS VERSUS R. ISHMAEL}

There is apparently no cult of holy relics in Judaism to be compared with the specific form of such a cult in The Story of Mar Pinhas. Nevertheless, at least some traces of such a cult do appear within the mediaeval forms of the Jewish cult of the so-called "Ten Martyrs" - ten sage rabbis allegedly put to death by order of Emperor Hadrian.

in Early Christianity, ed. by R. J. DALY (Holy Cross Studies in Patristic Theology and History), Grand Rapids, MI, 2009, pp. 127-142. The majority of scholars agree with R. Cantalamessa's second-century dating, although some others opt for the third century. Cf. R. CANTALAMESSA, L'omelia "In S. Pascha" dello Pseudo-Ippolito di Roma. Ricerche sulla teologia dell'Asia Minore nella seconda metà del II secolo, Milano, 1967. 
The Story of the Ten Martyrs was created in Byzantine Palestine somewhere between the late fifth and the early seventh centuries in an atmosphere of acute conflict with the Christian environment, and it is saturated with anti-Christian polemics. ${ }^{41}$ The "wicked Rome" who killed the martyrs is plainly a representation of the actual Christian empire of Byzantium. As Ra'anan S. Boustan notes, "[u]nlike those rabbinic sources that contest or ridicule Christian salvation history, The Story of the Ten Martyrs opts instead for a trenchant form of religious one-upmanship. It frames R. Ishmael's agonizing death as a testimony of God's love for the Jewish people that rivals Christian claims concerning Christ's atoning death." 42

The cult of the "Ten Martyrs" attained the highest level of popularity, which is witnessed in the proliferation of recensions of 'The Story of the Ten Martyrs 43 and the commemoration of the "Ten Martyrs" in the services of Yom Kippur and $9 A b$ up to the present. One of the recensions of The Story of the Ten Martyrs is preserved within the Hekhalot Rabbati ( $\S \S 107-121$ ). This fact is important to us, at least as a demonstration of the actuality of the cult and its hagiography in Babylonia. ${ }^{44}$ This story, which does not appear in the Hekhalot Rabbati, contains an account of the "relics" of the most prominent of the "Ten Martyrs", R. Ishmael. ${ }^{45}$ This account runs as follows (I quote Ra'anan S. Boustan's translation based on recension VII according to the edition by Reeg; some recensions do not contain the account we are interested in).

The face of R. Ishmael was so beautiful that the daughter of the emperor of Rome wished to ask her father to save his life, but the emperor refused. However, he presented to her the beautiful face of

(41) R. S. Boustan, From Martyr to Mystic: Rabbinic Martyrology and the Making of Merkavah Mysticism (TSAJ, 112), Tübingen, 2005, pp. 51-198.

(42) Ibid., p. 133.

(43) A critical edition of ten recensions: G. REEG, Die Geschichte von den Zehn Martyrern: synoptische Edition und Einleitung (TSAJ, 10), Tübingen, 1985.

(44) Cf. Boustan, From Martyr to Mystic, pp. 199-288.

(45) Cf. ibid., pp. 119-133; cf. especially pp. 130-133 about the antiChristian meaning of this episode. Cf. also R. S. BOUSTAN, "The Relics of Rabbi Ishmael in The Story of the Ten Martyrs," in: Jewish Understandings of the Other: An Annotated Sourcebook, <http://www.bc.edu/dam/files/research_ sites/cjl/texts/cjrelations/resources/sourcebook/relics_ishmael.htm> (accessed on 25 June 2014). 
R. Ishmael separately from his body - as the skin of his face, which was stripped off when R. Ishmael was alive. This countenance of $R$. Ishmael "is still kept in wicked Rome" (one has to notice this clearly anti-Christian actualisation of the story from an epic past) and, according to the legend, serves as the centrepiece of a strange ritual:

The countenance of R. Ishmael is still kept in wicked Rome (קלפדיין (קלסתר פניו של ר' ישמעאל ברומי הרשעה (2). And every seventy years, they (the Romans) take a healthy man and have him ride on [the back of] a cripple; they summon a man who proclaims before him: "Let him who sees, see; and anyone who does not see it, will never see." They place the head of R. Ishmael (ראשו של ר' ישמעאל) in the hand of the healthy man. They call the healthy man Esau and the cripple Jacob because of his limp. And they proclaim: "Woe to him when this one rises up for the sin of the other. Woe to Esau, when Jacob rises up for the sin of R. Ishmael's head," as it is written: I will wreak my vengeance on Edom through My people Israel (Ezek 25:14).

Saul Lieberman has shown that the ritual described above is patterned after the Roman Ludi saeculares (the games occurring only once during a human lifespan), especially according to their description in Suetonius (Claudius 21:2, for AD 47), including the riding of a healthy man on a limping man (although it was the limping man who was wearing a mask) and the herald's proclamation "no one had ever seen or would ever see again" (quos nec spectasset quisquam nec spectaturus esset) (s. Latin text in Suetonius, Claudius, 21:1, and also Greek in Herodian, History of the Roman Empire, 3:8:10, for AD 204 under Severus). ${ }^{46}$

Scholars mostly limit their analysis to the narrative of the maskritual with the face of $\mathrm{R}$. Ishmael. However, such a narrative would hardly arise in a milieu in which the severed countenance of R. Ishmael were not understood as endowed with a supernatural power of course, the mystical power of the divine face displaying itself through the faces of the righteous is the tradition responsible for the very origin of the term "Metatron," 47 and is thus one of the corner-

(46) S. Lieberman, Greek in Jewish Palestine, New York, 1942, 145. In the Babylonian Talmud ( $b$ 'Avodah Zarah 11b) a shortened recension of the same account is presented. Thus, it is probably earlier than the post-Talmudic Story of the Ten Martyrs, within which it is best preserved.

(47) LOURIÉ, "One hapax legomenon"; FLETCHER-LOUIS, “2 Enoch." 
stones of the corresponding mystical tradition. Unlike its "classical" predecessors in the Jewish Metatron and Merkabah mysticism, the story about the mask-ritual deals with the face of a righteous person that is separated from the righteous one himself, that is, it deals with a relic. Thus, regardless of its Roman pattern, the account of the mask-ritual is a witness of some liturgical veneration of the relics of Jewish martyrs. It needed to dispose of some (not necessarily R. Ishmael's) venerated relics as a material object, thus overcoming the aversion, normative for Judaism, to the impurity caused by a dead body.

The Roman mask-ritual is clearly presented as an inversion of some "correct" order. Both the inversion and its "correct" prototype must share as a common core some usage of holy relics. This kind of satire would make sense only for an audience that knows the mystical power of the martyrs' relics and is experienced in their ritual usage. Thus, the narrative of the Roman mask-ritual is not a polemical weapon per se but only a component of such a weapon, namely, an accessory of a cult. Such a situation is normative for hagiography, which often expresses some polemical attitudes but without becoming itself a means of a merely literary polemics (unlike the theological polemical treatises). Instead, it reflects the situation on the battlefield between the corresponding cults. It is the cults (rituals) themselves, and not the hagiography they produce, that shape the identities of the corresponding religious communities - although the cults use hagiography as an important tool, albeit one less important than the liturgy.

We have no need of going any deeper into the details of the Jewish ritual implied in the background of the story relating to the relics of R. Ishmael (after all, completely unknown to us), but we are now in a position to mark some features relevant to Jewish-Christian relations in "Babylonia" in the epoch when The Story of Mar Pinhas was composed.

The account of Mar Pinhas' martyrdom is a liturgical representation of the atoning sacrifice of Christ: it is patterned after the Eucharistic liturgy, and its data of commemoration is clearly referring to Great Friday. The atoning martyrdom of the "Ten Martyrs" also alludes to the atoning sacrifice of Christ but in a different way. Both traditions elaborate on the atoning meaning of the martyrdom. Such a resemblance between a Christian tradition and its Jewish counterpart is already somewhat unusual but it is further reinforced by the 
motives of the Metatron and Merkabah mysticism, especially if we identify the seventy-two "gods" of the murderers of Mar Pinhas with the seventy-two names of Metatron. And, finally, both traditions, the Christian one of Mar Pinhas and the Jewish one of the relics of R. Ishmael, refer to a cultic practice of the veneration of a martyr's relics.

Such a practice has an uncommon form even in the case of Mar Pinhas, where a particle of his relics substitutes for the entire body and is transformed into a "pearl," that is, a particle of the Eucharist. Identification of the two kinds of "pearls," that is, a particle of the relics and a particle of the Eucharist, is known elsewhere in Syrian Christianity, but such an accent on this identification is unusual. In the case of the Jewish counterpart, that is, the relics of R. Ishmael, the contrast with the mainstream religious tradition is even sharper, due to an obvious tension with the most widespread Jewish conceptions of ritual purity. The two traditions, Mar Pinhas' Christian one and $R$. Ishmael's Jewish one, fit together like two pieces of a unique puzzle.

\section{Proper NAMES: PinḤAS AND ANiṭa}

The name of Pinhas, biblical Phinehas (Phineas), was prominent in some pre-Christian Second Temple Jewish traditions (including the Samaritan tradition) as that of a high priest who made atonement for the people as a whole and a principal figure in the lineage of the legitimate priesthood. ${ }^{48}$ In at least some early Christian traditions,

(48) Cf. Ps 105:30 LXX (Greek only), Sir 45:23 (all versions) and 50:7 (Hebrew only); L. A. S. Monroe, "Phinehas' Zeal and the Death of Cozbi: Unearthing a Human Scapegoat Tradition in Numbers 25:1-18," Vetus Testamentum, 62 (2012), pp. 211-231; K. E. POMYKALA, "The Covenant with Phinehas in Ben Sira (Sirah 45:23-26; 50:22-24)," in: Israel in the Wilderness. Interpretations of the Biblical Narratives in Jewish and Christian Traditions, ed. by K. E. POMYKALA (Themes in Biblical Narrative. Jewish and Christian Traditions, 10), Leiden, Boston, 2008, pp. 17-36; B. G. WRIGHT III, "Ben Sira and the Book of the Watchers on the Legitimate Priesthood," in: Intertextual Studies in Ben Sira and Tobit. Essays in Honor of Alexander A. DiLella, O.F.M., ed. by J. CORLEY, V. SKEMP (The Catholic Biblical Quarterly. Monograph Ser., 38), Washington, D.C., 2005, pp. 241-254; O. Mulder, Simon the High Priest in Sirach 50. An Exegetical Study of the Significance of Simon the High Priest as Climax to the Praise of the Fathers in Ben Sira's Concept of the History of Israel (Supplements to the Journal for the Study of Judaism, 78), Leiden, Boston, 2003. 
Phinehas becomes a prototype of Christ. His lance is reconsidered as a typos of the lance that pierced the side of Christ. It is the Syrian tradition that provides the most explicit witness of this exegesis, in Ephrem the Syrian, Carmina Nisibena 39:7,49 as follows:

The lance of Phinehas filled me with fear,

That sword, with which he excluded the plague.

The lance that guarded the Tree of Life

Makes me joyful yet sad, for it excluded Adam from Life

Yet excluded the plague from the people. But the lance that wounded Jesus,

I [only] grieve for it; he was wounded, and I weep.

From him came forth water and blood;

Adam washed, came to life and returned to paradise.

However, the available texts of the early or mediaeval Christian traditions do not present Phinehas as an especially prominent priestly figure and one of the most important predecessors of Christ, as we would expect in the case of the continuation in Christianity of the appropriate Second Temple Jewish traditions. The Christian documents known to us at present seem to be insufficient to explain the choice of the name Pinhas for our hero. ${ }^{50}$

The name of Pinhas' main opponent, Aniha (אr), is otherwise completely unknown. Heis introduced as a "man" (حصir) of Simun (§ 4, p. 6/7; McCollum translates this as "attendant"), but his name,

(49) I quote according to R. MURRAY, Symbols of Church and Kingdom. A Study in Early Syriac Tradition. Revised ed., London, New York, 2006, p. 126; on the underlying exegetical tradition, s. here and especially in R. MURRAY, "The Lance which re-opened Paradise," OCP, 39 (1973), pp. 224-234, 491.

(50) This is not to say that some new data will never require a reconsideration ofsuch a conclusion. Cf., e.g., the complex textual history of the Book of Ben Sira in Syriac, whose lost earliest translation was probably closer to the Hebrew original (which, unlike its presently available Syriac version, witnessed the tradition of an exalted status of Phinehas): W. Th. VAN PEURSEN, Language and Interpretation in the Syriac Text of Ben Sira. A Comparative Linguistic and Literary Study (Monographs of the Peshitta Institute, Leiden. Studies in the Syriac Versions of the Bible and their Cultural Contexts, 16), Leiden, Boston, 2007, p. 12 et passim. The Story of Mar Pinhas develops as well some Moses typology - for example, when saying that Mar Pinhas passed eighty years in his ascetic life before his martyrdom $(\S 3, \mathrm{p} .4 / 5)$. The number eighty seems to allude to Moses' age at the moment of Exodus (Ex 7:7), even though Mar Pinhas left the world at the age of twenty (ibid.); thus at the day of his martyrdom, he was 100 years old. 
unlike that of Simun, could not be explained from Persian. However, it is tempting to explain it as the name of two (in some recensions, one) of the "Ten Martyrs," Hanina (חנינא, a variant of the name Haninah/Hananiah), written down in reverse order and slightly modified to preserve the ending with $-a$ (which would result in *Aninha but further or immediately simplified into Aniha).

Anagrams and other modifications of names for magical purposes are known in texts in Aramaic. There is an incantation bowl where the name of Jesus is probably written in reverse order. This text contains the words "In the name of Bar Mesusia' (br mswsy'), the great Ineffable Name," but the name Mesusia' is unknown elsewhere. Markham J. Geller explained this name as "the son of the mother of Jesus", that is, Jesus himself, where the letters swsy represent the name Jesus (ysws) written down in reverse order, and the two remaining letters $m$ and ' represent the word ' $m$ ("mother"), also written in reverse order, the two words being connected according to the known Aramaic anagram pattern of letters within letters and a name within a name. ${ }^{51}$ The transformation of the name Hanina into Aniha would be simpler but, probably, no less magically effective.

\section{SYRIAN MONASTICISM FROM ATHENS}

The place of origin of Mar Pinhas is mentioned, in the Syriac text, in somewhat contradictory fashion: "The blessed Mar Pinhas was, by family, from the city of Atines [sc., Athens - B. L.], that is Tanis

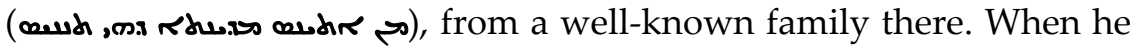
was twenty years old and had already been instructed in philosophy, his parents died..." (§3, p. 4/5); the Arabic text mentions "the city of Athens (مدينة (ثيناس)" uniquely (p. 34/35 txt/tr.). I quoted the translation of McCollum, who accepted, after Fiey ${ }^{52}$ and Bedjan, ${ }^{53}$ the identifica-

(51) M. J. GelleR, "Jesus' Theurgic Powers: Parallels in the Talmud and Incantation Bowls," Journal of Jewish Studies, 28 (1977), pp. 141-155 (154), based on the reading proposed by J. A. MONTGOMERY, Aramaic Incantation Texts from Nippur (University of Pennsylvania. The Museum. Publications of the Babylonian Section, 3), Philadelphia, 1913, p. 24.

(52) J. M. FIEY, Assyrie Chrétienne. Contribution à l'étude de l'histoire et de la géographie ecclésiastiques et monastiques du nord de l'Iraq (Recherches publiées sous la direction de l'Institut de lettres orientales de Beyrouth, 23), Beyrouth, [1965], p. 738, refers to Bedjan without any discussion.

(53) Who adds the following footnote in Syriac: "In the land of Egypt, Tanis (_) ?)"; P. BedjAN, Acta martyrum et sanctorum, IV, Parisiis, 1894, 
tion of awd (Tnnys) with an Egyptian town, Tanis, in the northeastern Nile delta (pp. $x v-x v i, 20)$. This identification, however, is merely a guess presuming that the second $n$ in Tnnys is added erroneously. The text never mentions Egyptian realities, although, indeed, Mar Awgen's monastic tradition did have an Egyptian origin. Thus, Bedjan's guess concerning Tanis is certainly plausible and, moreover, as McCollum shows, it fits the topography of Mar Pinhas' route to the place of his ascetical life.

However, the mention of Athens is certainly not accidental, even though McCollum is, most probably, correct in stating that it is not genuine. An Athenian origin for an ascetic comes into fashion in the Syrian anti-Chalcedonian ("monophysite") hagiography at some point in the seventh century ${ }^{54}$ - certainly under the influence of the Syriac translations of the Corpus Areopagiticum. Other witnesses to the same fashion are "Pseudo-Pseudo-Areopagitic" works (especially his "Autobiography" CPG 6633, Syr. tr. BHO 255.3, and the astronomical treatise known only in Syriac, CPG 6634) appearing in the sixth or seventh centuries in the same Syrian ("monophysite") milieux. The Church of the East, on the contrary, remained untouched by these waves of storm-like Dionysian influence..$^{55}$ However, the Acts of Mar Pinhas are presently available to us, in either Syriac or Arabic, in the

p. 210, fn. 1. In Syriac, $\sim_{5}$ could be the name of different towns (incl. Zoara in Palestine) but, as the name of a town in Egypt, it must mean Tanis.

(54) S., on an important Syrian hagiographical work of this epoch, B. LOURIÉ, "S. Alypius Stylite, S. Marc de Tharmaqa et l'origine des malke'a éthiopiennes," Scr, 1 (2005), pp. 148-160. St. Marc of Tharmaqa, a legendary hermit in northern Ethiopia, originated from Athens. In his Life, the motive of a 40-day journey to the dwelling place of an ascetic is also present (cf., in Mar Pinhas' case, § 3, p. 4/5), but, of course, the ultimate source of this motive is Elijah's 40-day journey to Mt Horeb (1 Kings 19:8).

(55) As it has been recently shown by Emiliano Fiori, whose paper "Dionysius the Areopagite and Isaac: an Attempt of Reassessment" is still unpublished in its English original but has already appeared in a Russian translation: Э. ФьОРИ, “Дионисий Ареопагит и Исаак Сирин: попытка переоценки," in: Преподобный Исаак Сирин и его духовное наследие. Материалы Первой международной патристической конференциии Общецерковной аспирантуры и докторантуры имени святых Кирилла и Мефодия, Москва, 10 11 октября 2013 2., под ред. митр. Волоколамского ИлАРИОНА, Москва, 2014, pp. 288-307. I am grateful to Alex Simonov for bringing my attention to this publication and to Emiliano Fiori for providing me with his unpublished work in English. 
"monophysite" recensions only, soit is reasonable to attribute the appearance of "the city of Athens" in our text to the responsible "monophysite" editor.

\section{CONCLUSIONS}

My main conclusion from the analysis above is to offer my warmest gratitude to Adam McCollum, who has brought to our attention this work of Syrian hagiography, a work that is so important in a number of different ways. ${ }^{56}$

(56) And I am also very grateful to Nikolai Seleznyov for his continuous help in various matters related to Syrian Christianity and to Claudia Jensen for improving my English. 